\title{
OBITUARY
}

\section{N. BISHOP HARMAN}

Nathaniel Bishop HaRman, whose death was briefly announced in our pages last month, was born in London in 1869. Educated at the City of London School, he was a scholar of St. John's College, Cambridge, and graduated with a double first in the Natural Sciences Tripos in 1897. Coming to London he joined the medical school of the Middlesex Hospital, where he came under the influence of William Lang, with whom he worked in the Eye Department for many years as clinical assistant. He took the M.B., B.Ch.Cantab. and the F.R.C.S.Eng. in 1898 and did a great deal of anatomical teaching both at Cambridge and in London, before he went out to South Africa as a Civil Surgeon in the Boer War. For his service he had the Queen's medal with five clasps. At Moorfields he worked with Treacher Collins, who in the early years of the present century had a remarkable band of chief "clinical assistants, among them, Hancock, Mayou and Bishop Harman.

He was elected ophthalmic surgeon to the Belgrave Hospital for Children and later to the West London Hospital, where he was also lecturer in ophthalmology at the post-graduate medical school.

Ophthalmologically speaking, he will be best remembered for the work which he did with the late James Kerr in the foundation of special classes in the schools of the L.C.C. education authority, where partially sighted children were segregated and taught by special methods. Later these classes were centralized at various schools for the defective sighted which were called myope schools. In this work he was truly a pioneer, and it has had a lasting influence on the prevention of blindness, a subject in which he was always keenply interested. Harman served as consulting ophthalmologist to the L.C.C., and later played a leading part in setting up the National Eye Service. Much of his spare time was spent in furthering the work of the B.M.A. For ten years he was Treasurer of the Association, he received its gold medal in 1931, and quite recently was honoured by being elected a vice-president. During the 1914-18 War he was joint secretary of the Central Medical War Committee. And he was a Direct Representative on the General Medical Council for a period of years.

Harman joined the Ophthalmological Society of the United Kingdom 45 years ago and contributed many papers to its Transactions. He was a prolific author, and his "Aids to Ophthalmology" reached its eighth edition. It is one of the best of the "Aids" series, and has been the mainstay of the knowledge of eye diseases of many a medical student. His diaphragm test for binocular vision was demonstrated at the Ophthalmological Society in 1909, and immediately became a most popular instrument, of great help in 
detecting malingerers. He was gifted with marked manual dexterity, and several useful modifications of ophthalmic instruments are due to him.

With his flaxen hair and tall stature he presented a distinguished appearance. At times militant, as the writer remembers him at a meeting of the members of the honorary staffs of the London Hospitals, with Sir Rickman Godlee.in the chair, before the passing of the National Insurance Act; and as he got older, looking more benevolent, he was always worth listening to. Whether he was demonstrating his diaphragm test, or in lighter moods, when showing a pair of green glasses which had come from Delhi during the Mutiny, he commanded attention and respect.

He had a singularly alert brain, and was a good speaker with a ready sense of humour. British ophthalmology owes him a deep debt of gratitude, and much of his work will stand the test of time and not be forgotten. To his widow, herself a qualified doctor, and his four children we offer the sincere sympathy of British ophthalmology in their bereavement.

\section{DR. GORDON NORRIE}

News of the death of Dr. Gordon Norrie of Copenhagen on October 11, 1941, has just reached us. He was fortunate in that he died after a very short illness, and before the worst horrors of the German occupation of Denmark had begun.

Of Scottish ancestry, Dr. Norrie was born May 6, 1855, in Elsinore, the son of William Gordon Norrie and his wife, Fanny Wright. He was educated in Copenhagen, practised speaking English with - his grandfather, who had gone from Scotland to settle' as a merchant in Denmark, and entered the University of Copenhagen in 1873. He qualified as a surgeon in 1880 , and was studying ophthalmology under Professor Hansen Grut from 1879-1885. From 1885 onwards he practised in Copenhagen. He was surgeon to the Royal Institute for the Blind for 35 years, and commander of the military clinics of ophthalmology in Copenhagen from 1894-1912. He held rank in the army medical department from 1891-1918, and his last six years of service were as Commander of the Garrison Hospital in Copenhagen, with the rank of Colonel. He also served the Board of Health for a great many years, and was its vice-president for 20 years. To our columns he contributed a paper on ophthalmia neonatorum in Denmark, and in 1938 we gave a short abstract of his experiences at the Royal Institute for the Blind.

Gordon Norrie was an authority on medical history, and particularly on the history of ophthalmology. His "Den Danske Oftalmologis Historie indtil aar 1900 " appeared in 1925, and he was so kind as to send a copy to the writer of this note.

At the 450 years celebrations of the University of Copenhagen, he was created M.D. honoris causa. 